\title{
Diversity of cyanobacteria in man-made solar saltern, Petchaburi Province, Thailand - a pilot study
}

\author{
Thomrat Chatchawan ${ }^{1}$, Yuwadee PeErapornPISAL ${ }^{1} \&$ Jiří KomÁReK $^{2 *}$ \\ ${ }^{1}$ Department of Biology, Faculty of Science, Chiang Mai University, Chiang Mai, Thailand. 50200 \\ ${ }^{2}$ Institute of Botany, Academic of Science of the Czech Republic, Třeboň. Czech Republic, 38972; *corresponding \\ authore-mail: komarek@butbn.cas.cz
}

\begin{abstract}
Solar salterns can be found in many tropical and subtropical regions throughout the world, however, nothing is known from these habitats in Southeast Asia. The Petchaburi solar salterns are located in Petchaburi Province, middle part of Thailand. These areas can be defined as hypersaline biotopes where, in salt-producing times, salinity increases by more than 10 times that of seawater. The annual salinity gradient of these areas ranges from $0-35$ ppt. in the non salt-producing period and gradually elevates from more than 35 ppt. up to saturation in the salt producing period, when salt crystals are formed. The cyanobacterial samples were collected from four ponds of the Petchaburi saltern during the salt producing period (November - December 2009), when the range of salinity was from $90-250$ ppt. pH values of soil samples ranged from $7.9-8.1$ and conductivity from $164-$ $350 \mathrm{ds} / \mathrm{m}$. Other physico-chemical parameters were analyzed in the soil samples as well. Cyanobacterial mats and their filaments predominated among the diatoms. Sixteen species of cyanobacteria were found. Dominant species were Spirulina subsalsa, Coleofasciculus cf. chthonoplastes and Oscillatoria lloydiana. Most of the species found in this study have not yet been reported in Thailand. Species, which did not correspond to any described taxa in scientific literature (new species or unknown modifications) are designated by "cf." or "sp.".
\end{abstract}

Key words: biodiversity, cyanobacteria, halophiles, halotolerants, hypersaline environments, solar salterns, Thailand

\section{Introduction}

Hypersaline environments are habitats where salt concentration is in excess of seawater $(3.5 \%$ of total dissolved salt). For example, hypersaline habitats include salt lakes, salt flats, hypersaline lagoons, hypersaline sulfur spring etc. (DASSARMA \& ARORA 2001). These habitats are classified as extreme environments because high salt concentrations are hostile to most organisms. However, many organisms, particularly prokaryotic and eukaryotic microorganisms, can inhabit and survive in these environments due to their ability to cope with osmotic stress. These microorganisms have many mechanisms to protect their cells from high osmotic pressure and against the denaturing effect of salts. The most common adaptation is accumulation of osmolutes or compatible solutes (DenNis \& Shimmin 1997; Gilmour 1990; Oren 2000).

Man-made solar salterns are also defined as hypersaline extreme habitats. They can be found in many tropical regions throughout the world and are mainly used for $\mathrm{NaCl}$ productions. Among other organisms, these habitats are colonized by large populations of microorganisms including bacteria, archaea, fungi, algae and cyanobacteria (Satyanaraya et al. 2005). Cyanobacteria play the principal role as primary producers in saltern environments. They are commonly found predominantly in unicellular and filamentous forms and usually developed on the bottom of evaporization ponds among other eukaryotic algae (mostly Chlorophytes and diatoms).

In Thailand (and SE Aisa), the diversity of cyanobacteria in hypersaline environments such as solar salterns (cf. Table 1) has not yet been reported, therefore the purpose of this pilot study was to investigate the composition and biodiversity of cyanobacteria occurring in a man-made saltern in Petchaburi province, Thailand. 


\section{Material and methods}

The samples were investigated during a salt producing period (November- December 2009) in four artificial ponds of a solar saltern, located at $13.30 \mathrm{~N}$ latitude and 100.07 E longitude at 5 meters above sea level in Ban Laem district, Petchaburi province, Thailand (Fig. 1). The study area is approximately $14400 \mathrm{~m}^{2}$ and $1 \mathrm{~km}$ far from the sea (Chao Sam Ran beach), surrounded by mangrove forests, and on one side by a road. The entrance is from Ban Laem village. This area is mainly used for sea-salt production. The salt is produced throughout the year except during the rainy season. The salinity gradient was $0-35 \mathrm{ppt}$. in the rainy season and gradually increased in the salt-producing period from more than 35 ppt. up to more than 400 ppt. in the areas of salt production. Higher plants were absent in these ponds, however many species of mangrove forest, including Rhizophora apiculata, Avicennia marina and Thespesia populnea, were found in the surrounding areas of salt field.

The study was conducted using standard methods. Cyanobacterial samples were collected from wet soil of shallow water of evaporation basins (with periodical drying) and preserved in $2 \%$ formaldehyde. Some physico-chemical parameters of soils were analyzed including conductivity, $\mathrm{pH}$, salinity, soil ionic composition and total organic matters.
Cyanobacterial specimens were observed under optical microscopy (Olympus BX51) with different (up to 1000x) magnifications. Identification of cyanobacteria was examined according to KOMÁREK \& ANAGNOSTIDIS (1998, 2005). The morphology of strains was documented by digital photography techniques.

The isolation and cultivation of cyanobacteria for further study (molecular, ecological characteristics) were also carried out. A small amount of each soil sample (approximately 5 gr.) was plated onto BG-11 agar medium with various salt concentrations and then the soil was spread throughout the medium. All cultures were maintained under the following conditions: Temperature at $25{ }^{\circ} \mathrm{C}, 12: 12$ light:dark cycle and light intensity at $28 \mu \mathrm{mol} \cdot \mathrm{m}^{-2} \cdot \mathrm{s}^{-1}$. After 1 month of cultivation, each cyanobacterial species was isolated and transferred into new agar medium. Isolation was done continuously until monospecific strains were obtained. The strains were used to conduct ecophysicological experiments and will be described in detail in another study.

The dependence of growth under salinity gradients was studied. The selected strains (Leptolyngbya sp. 1, Nostoc sp.1, Nostoc sp. 2 and Trichormus/Wollea sp.) were cultivated in 96 wells serological plates, in salinity ranging from 0 to $40 \%$ o of $\mathrm{NaCl}(0 \%$, 2\%o, 6\%o, 10\%о, 15\%о, 20\%о, 25\%о, 30\%o $35 \%$, $40 \%$ ), under temperature around $30{ }^{\circ} \mathrm{C}$ and

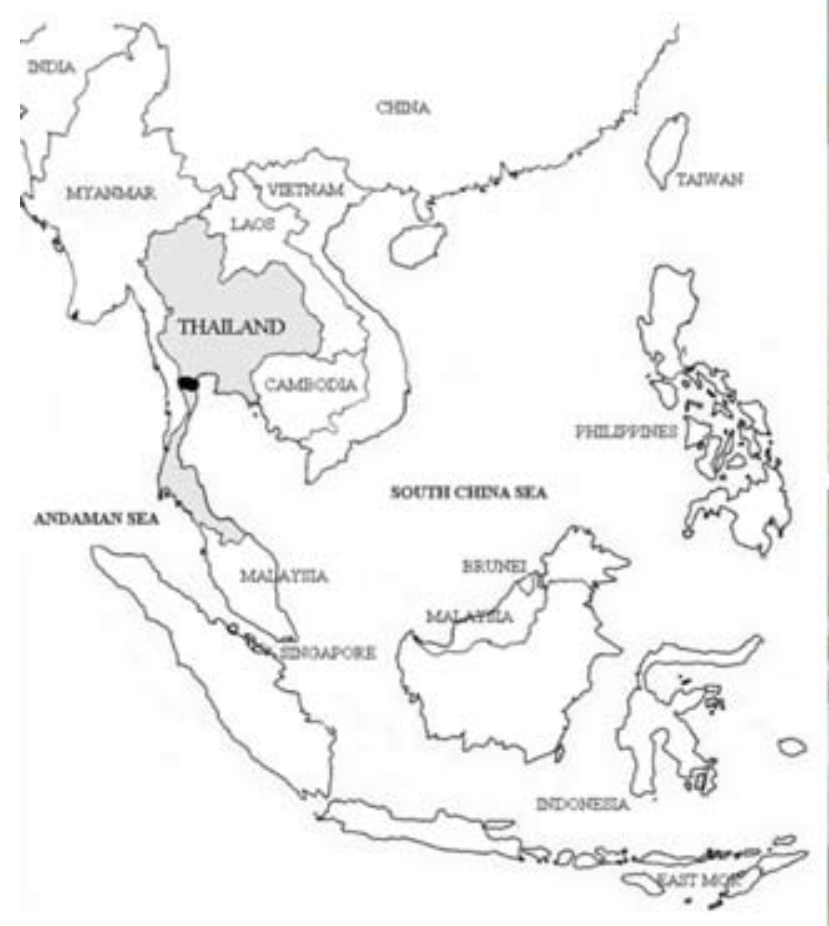

- PETCHABURI
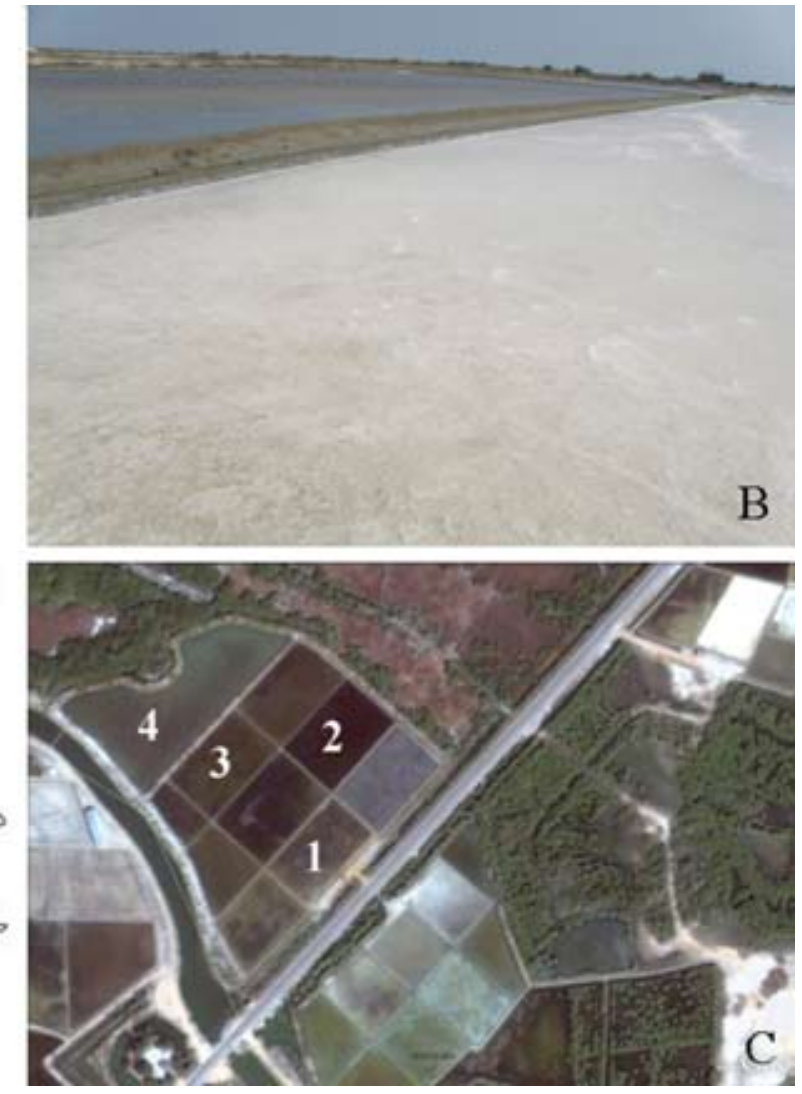

Fig.1. (A) Map of Southeast Asia, location of Petchaburi province, Thailand; (B) Study site, solar saltern in Petchaburi province; (C) Aerial photograph of saltern areas in Petchaburi province; (according to Google Earth version 5.0). 
Table 1. Some physico-chemical properties of soil samples of four selected sites with different salinity.

\begin{tabular}{ccccccc}
\hline $\begin{array}{c}\text { Sampling sections } \\
\text { (ponds) }\end{array}$ & $\begin{array}{c}\text { Salinity } \\
(\mathrm{ppt})\end{array}$ & $\mathrm{pH}$ & $\begin{array}{c}\text { Organic matters } \\
\left(\mathrm{g} .100 \mathrm{~g}^{-1}\right)\end{array}$ & $\begin{array}{c}\mathrm{EC} \\
\left(\mathrm{dS} . \mathrm{m}^{-1}\right)\end{array}$ & $\begin{array}{c}\mathrm{Na}^{+} \\
\left(\mathrm{mg} . \mathrm{kg}^{-1}\right)\end{array}$ & $\begin{array}{c}\mathrm{Ca}^{2+} \\
\left(\mathrm{mg} . \mathrm{kg}^{-1}\right)\end{array}$ \\
\hline No.1 & 90 & 7.9 & 2.49 & 164.1 & 12.9 & 6.81 \\
No.2 & 125 & 7.9 & 3.74 & 349.6 & 24.0 & 12.02 \\
No.3 & 150 & 8.0 & 3.41 & 340.5 & 18.2 & 28.10 \\
No.4 & 249 & 8.1 & 2.33 & 397.5 & 14.0 & 28.38 \\
\hline
\end{tabular}

light intensity $32 \mu \mathrm{mol} \cdot \mathrm{m}^{-2} \cdot \mathrm{s}^{-1}$. The optical density (absorbance:OD) at $750 \mathrm{~nm}\left(\mathrm{~A}_{750}\right)$ was measured daily by iEMS plate Reader, LabSystems, Ltd., Finland.

\section{Results}

Numerous forms of cyanobacteria (colonies, mats, thallus, filaments, etc.) were collected from four ponds with different salinities, namely from pond no.1 (90 ppt), pond no.2 (125 ppt), pond no.3 (150 ppt) and pond no.4 (249 ppt). In total, sixteen cyanobacterial species were found. Most of them belong to filamentous types (Table 2; Figs 2,3). Dominant species were Spirulina subsalsa Oersted ex Gomont, Oscillatoria lloydiana Gomont and Coleofasciculus cf. chthonoplates (Thuret ex Gomont) Siegesmund et al. Four new taxa records for Thailand were found from this study, including $O$. lloydiana, Johannesbaptistia pellucida, Halothece/Euhalothece sp. and Halomicronema sp. Several studied species or up to now unknown modifications were detected (the Petchaburi salterns belong to extreme hypersaline habitats in a region, from which do not exist other studiesabouthalophilic cyanobacterialvegetation). Such taxa are designated by marks "cf." or "sp." and are presented for further research.

The number of species declined with increasing salinity (Table 1 ). The salinity gradients during the studied periods varied from 90-249 ppt. $\mathrm{pH}$ was slightly different in each site, ranging from 7.92-8.05. $\mathrm{Na}^{+}$and $\mathrm{Ca}^{2+}$ values tended to be higher with increasing salinity. Other physicochemical properties of the soils from each site are presented in Table 1. The list of isolation strains are shown in Table 2. In the following taxonomic part, dominant and some rarely known species are described with more detail.

\section{Taxonomic part}

\section{Aphanothece cf. halophytica Hof et FrémY}

Colonies multicellular, macroscopic; sheaths present, colourless, firm; cells blue-green to olive-green, widely oval to cylindrical, arranged loosely and distributed in many direction, (3) $4 \times$ (6) $7 \mu \mathrm{m}$; cell contents net-like with granules; cell divisions in one plane perpendicular to longitude of cell axis. - Note: This species is similar with Aphanothece halophytica of HoF and FRÉMY, but this species is published in different conceptions and its taxonomy is still unclear. Occurrence: It usually grows among other cyanobacteria in blue-green to brownish mats on the wet soil surface. This species was distributed in most areas of study where salinity ranged from $90-150 \mathrm{ppt}$.

\section{Chroococcus sp.}

Solitary or 2 cells, small microscopic colonies; cells olive-green, hemispherical, $5.4-8.5 \mu \mathrm{m}$ in diameter, with sheaths up to $17 \mu \mathrm{m}$ in diameter; cell contents homogeneous; sheaths colourless, delimited, firm, usually two gathered cells in one sheath. - Note: In comparison with other descriptions, our specimens are not similar with any known species. Occurrence: It was found in blue-green mat on wet soil surface, solitary among other cyanobacteria.

\section{Coleofasciculus cf. chthonoplastes (ThURET ex Gomont) Siegesmund et al. (Fig. 3a)}

Thallus very densely compact but smooth and soft, mucilaginous, usually attached on the soil surface, sometimes mixed with other cyanoprokaryotes or other algae, particularly diatoms, dark green or olive-green; sheaths present, colourless and thick, usually opened; trichomes bright bluegreen, 3.2-4.3 $\mu \mathrm{m}$ wide, \pm straight but sometimes slightly curved; there are many trichomes in the same sheath, usually packed in fascicles, with slight constrictions at cross-walls; cells a little 
longer than wide, 3.5-4.5 $\mu \mathrm{m}$ long; apical cells acute-conical; hormogonia present. - Note: Our populations are a little different from the description of KomÁreK \& ANAgnostidis (2005) in shape of cells, which are usually longer than wide in our populations. Occurrence: It usually grows in blue-green mats on a wet soil surface, or sometimes in a green thallus soaking in water. Thick filaments are attached to the soil surface and soaking in water. Occur throughout the whole study area. This is a cosmopolitan species and distributed worldwide.

\section{Cyanosarcina sp.}

Colonies microscopic, spherical, composed of densely arranged cells, forming packet-like aggregates, to $15 \mu \mathrm{m}$ in diameter; sheaths around colonies thin (up to $2 \mu \mathrm{m}$ thick), firm, tightly surrounding cell clusters; cells irregularly rounded, blue-green, 0.7-1.5 $\mu \mathrm{m}$. - Note: Our species does not correspond with any other described taxon. Occurrence: It was found in pale to dark bluegreen mat on soil surface with soaking water and occurred only in sites where salinity is around 90 ppt.

\section{Halomicronema sp. (Fig. 2c)}

Non heterocytous, filamentous, not branched; trichomes blue-green, cylindrical, approximately $0.7-1.8 \mu \mathrm{m}$ wide; not constricted at the crosswalls; sheaths not distinct; apical cells rounded, immotile. - Note: Our specimens differ little in width in comparison with the original description of Halomicronema excentricum ABED et al. We are not sure if our species is the same or only variable in size in comparison with the original species or if it is another taxon. Confirmation by molecular sequencing is necessary. Occurrence: It was found mixed with other cyanobacteria in green filamentous mats on a wet soil surface, and occurred in sites where salinity was lower than 100 ppt. The species still is little known. It was first described by ABED et al. (2002) from benthic microbial mats in a man-made hypersaline pond in Eilat (Israel), but it is probably more widely distributed.

\section{Halothece/Euhalothece sp. (Fig. 2a)}

Cell solitary, blue-green to olive-green, $6 \mathrm{x}$ $8 \mu \mathrm{m}$, widely oval; cell content net-like with granules; motility not observed. - Note: Our species is similar to the description of Halothece californica MARGHERI et al. (2008), but the genus Halothece contains more than one species from various hypersaline habitats (GARCIA-PICHEL et al. 1998) and the identity was not yet confirmed. Occurrence: It was found in mats with other cyanobacteria on wet to dry soil surfaces. This organism is little known. It was found in mats from many hypersaline environments.

\section{Johannesbaptistia pellucida (DICKIE) TAYLOR et Drouet (Fig. 2b)}

Solitary pseudofilaments, unbranched, straight or slightly waved, occasionally variously curved; cells bright blue-green, olive-green, sometimes yellow-green to brownish, discoid or rounded lenticular, 2(4.6) $\times 6.6 \mu \mathrm{m}$, arranged in one row; cells enveloped by a wide mucilage, which is colourless, tube-liked shaped, and rounded at the end; spaces between cells are distinct and clear; cell contents finely granular; numerous necridic cells are present in pseudofilaments. Note: Our specimens are in agreement with the wide description of this species (KOMÁREK \& AnAGNOSTIDIs 1999). Occurrence: It was usually found in a green-brownish mat, on a dry soil surface, and occurred only in sites where salinity is around $90 \mathrm{ppt}$.

\section{Komvophoron sp.}

Trichomes small, always straight, solitary among other cyanobacteria, short or up to $60 \mu \mathrm{m}$ long, immotile, deeply constricted at cross-walls; sheaths not observed; cells pale blue-green, mostly barrel-shaped, longer than wide, $0.1-0.8 \times 0.1-$ $1.2 \mu \mathrm{m}$; cell contents homogeneous; apical cells rounded without thickened cell walls and calyptra. - Note: Our populations do not correspond to the description of any known species. Komvophoron from hypersaline habitats are little known and need further revision. Occurrence: It was usually found in pale to dark blue-green mats with soaking water and always occurred (few filaments) mixed with other cyanobacterial species, presented only in the areas with salinity lower than $150 \mathrm{ppt}$.

\section{Leptolyngbya sp. 1}

Filamentous; filaments long, not branched, usually in clusters, slightly waved with colourless facultative sheaths; trichomes blue-green to olivegreen, very thin less than $2 \mu \mathrm{m}$ wide; apical cell rounded; hormogonia not observed; heterocytes and akinetes absent. - Note: Not identifiable 

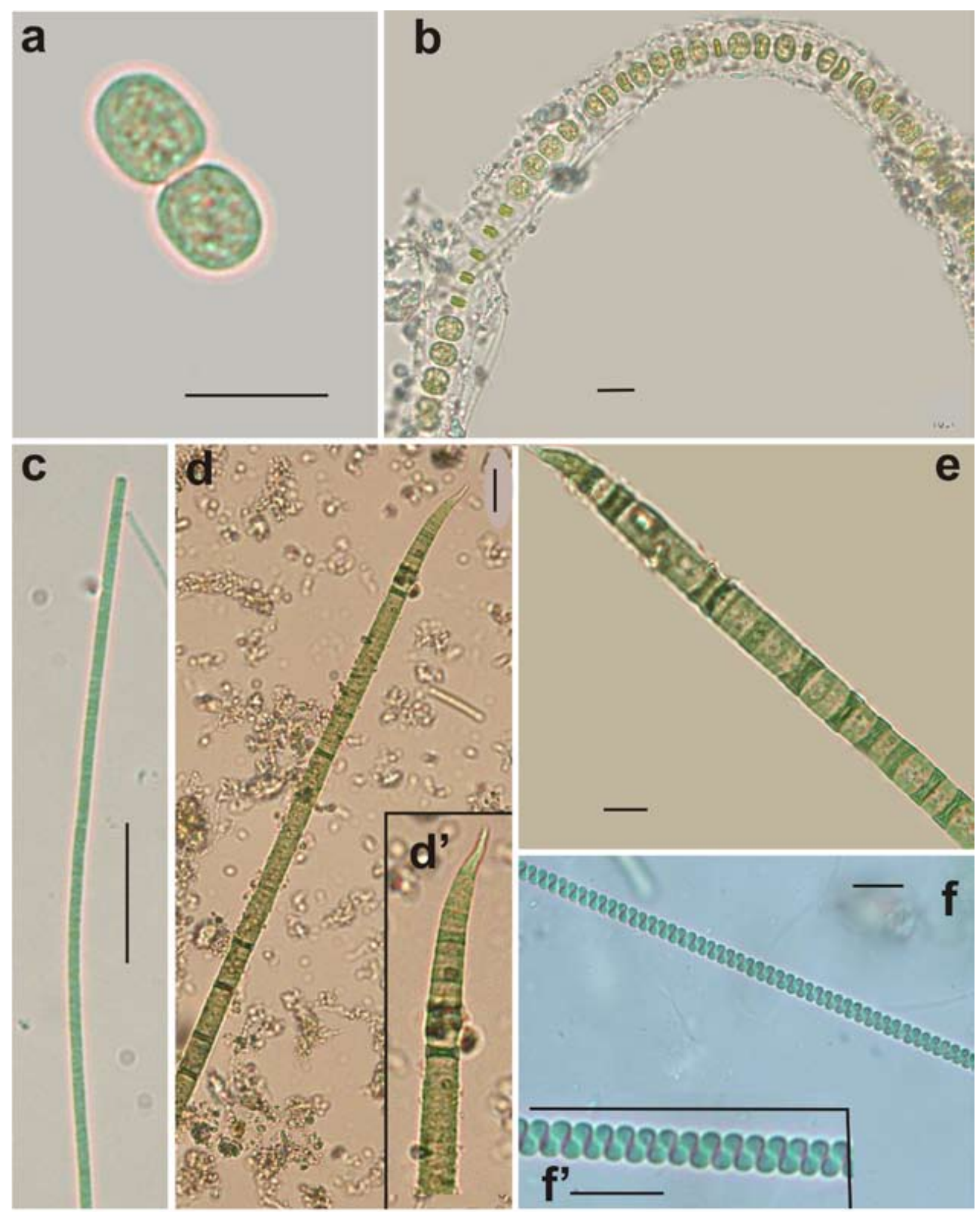

Fig. 2. Dominant and some characteristic species found in the Petchaburi saltern: (a) Halothece/Euhalothece sp.; (b) Johannesbaptistia pellucida; (c) Halomicronema sp.; (d-e) Oscillatoria lloydiana; (f) Spirulina subsalsa. All specimens from natural samples. Scale bar $10 \mu \mathrm{m}$. 

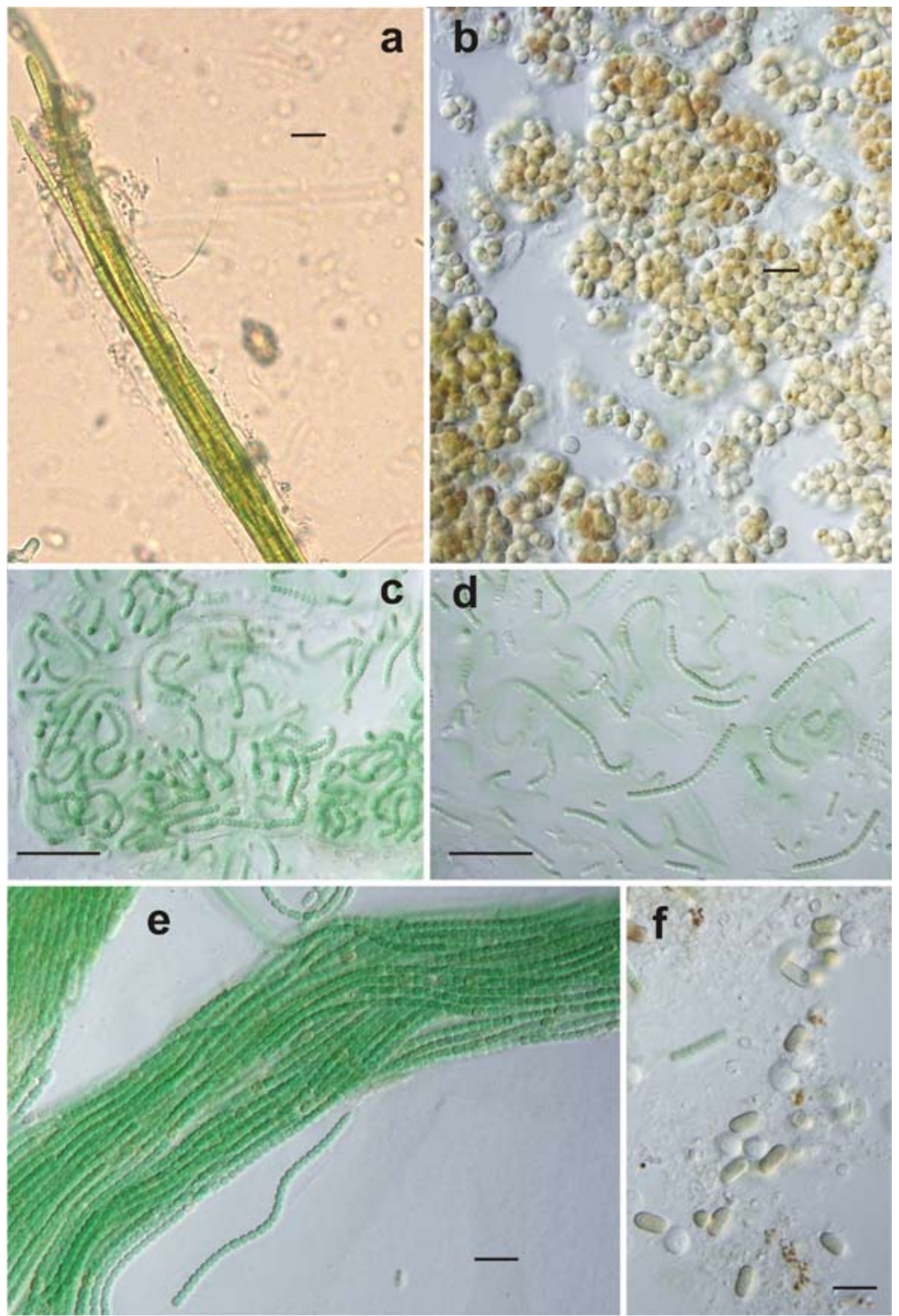

Fig. 3. Dominant and some characteristic species found in the Petchaburi saltern: (a) Coleofasciculus cf. chthonoplates; (b) Nostoc sp. 1 (from BG-11 agar medium with $10 \% \mathrm{NaCl}$ ); (c-d) Nostoc sp. 2 (from BG-11 agar medium); (e) Wollea sp. (from BG-11 agar medium); (f) liberated akinetes of Wollea sp. Scale bar $10 \mu \mathrm{m}$. 
according to literature available. Occurrence: It usually grows in blue-green mats on wet soil surfaces, but also sometimes in dry mats mixed with other cyanobacteria.

\section{Leptolyngbya sp. 2}

Filamentous; filaments long, thin, spiral, not branched, usually living solitary, slightly waved, with colourless facultative sheaths; trichomes blue-green, very thin up to $3 \mu \mathrm{m}$ wide; hormogonia not observed; heterocytes and akinetes absent. Note: Our species does not correspond with any description of halophilic Leptolyngbya species. Occurrence: It grows in blue-green mats on the wet soil surface and usually occurs among other cyanobacteria. This species was found in sites where salinity is around $90 \mathrm{ppt}$.

\section{Lyngbya sp.}

Filaments straight, \pm slightly curved, long, living solitary, rarely in clusters, $20 \mu \mathrm{m}$ wide; sheaths present, thin, firm, colourless to sometimes yellow-brownish, only one trichome in a sheath; filaments not branched; trichomes blue-green, olive-green to yellow-brownish, cylindrical, 11-15 $\mu \mathrm{m}$ wide, not constricted at cross-walls; cells discoid, usually shorter than wide, mostly $1 / 3$ as long as wide, 3-5 $\mu \mathrm{m}$ high; apical cells widely rounded without thickened outer cell walls; hormogonia and necridic cells are present. - Note: Our specimens does not correspond to any described taxon. Occurrence: Found in pale to dark blue-green mats on wet soil surface, sometimes on soils with soaking water. It was usually present among other cyanoprokaryotes, found only in the study sites with salinity lower than $150 \mathrm{ppt}$.

\section{Nostoc sp. 1 (Fig. 3b)}

Colonies brown to dark green with an irregular shape, approximately up to $1 \mathrm{~cm}$ in diameter, with a rough surface; filaments densely agglomerated and coiled within sheaths; sheaths little yellowbrownish to colorless; trichomes brown, yellow-brownish to olive green, not branching; cells spherical, slightly oval to irregular oval (variability in shape), 3-4.5 $\mu \mathrm{m}$ in diameters; morphology of apical cells not different from other cells; heterocytes and akinetes not observed in culture. - Note: Not identifiable according to present literature. Occurrence: This species was found only in culture isolated from the soil. It also grew among other cyanophytes in the first period of isolation but the growth time of this species is very slow.

Nostoc sp. 2 (Fig. 3c-d)

Colonies green with a rough surface, mucilaginous, of irregular shape; loosely packed filaments, which are coiled in sheaths; sheaths colorless; trichomes green, waved, not branched; cells with similar size along the whole filament, spherical to slightly oval, very small, less than $1 \mu \mathrm{m}$ in diameter; heterocytes and akinetes absent in culture. - Note: Not identifiable according to present literature. Occurrence: This species was registered only from culture, isolated from the soil. It grew together with other cyanophytes in the first period of isolation.

\section{Oscillatoria lloydiana Gomont (Fig. 2d-e)}

Thallus dark blue-green, tightly packed with soil particles; trichomes blue-green to olive-green, sometimes mixed with other cyanoprokaryotes, very long, solitary or sometimes clustered; trichomes without sheaths, not constricted at the cross walls, 7.5-9 $\mu \mathrm{m}$ wide, a little arcuated at the ends of trichomes; cells shorter than wide, 2.2$2.8 \mu \mathrm{m}$ long; apical cells pointed; hormogonia sometimes present. - Note: Our species differs little from the description of KOMÁREK \& ANAGNOSTIDIS (2005) in terms of size of cell width. Occurrence: This species was usually found in bright to dark blue-green mats, tightly packed on the wet soil surface of a nearly drained channel; sometimes bubbles occurred in mats. Distributed in the whole area.

\section{Spirulina subsalsa Oersted ex Gomont (Fig. 2f)}

Trichomes pale to bright blue-green, loosely clustered among other cyanoprokaryotes, sometimes they occur as solitary, spirally coiled, straight, or variously curved, short to very long, from 50 to more than $300 \mu \mathrm{m}$ long; coils with right-handed screw-like rotation, each coil regularly tightly joined to another, nearly parallely arranged, 2.5-4.5 $\mu \mathrm{m}$ wide, $1.8-2 \mu \mathrm{m}$ high; sheaths absent; apical cells rounded. - Note: Our species corresponds to the description of KOMÁREK \& ANAGNOSTIDIS (2005). Occurrence: It was usually found in blue-green mats on soaked soil surfaces, rarely in a dry mat. Occurred in all studied sites. This species probably has a cosmopolitan distribution. 


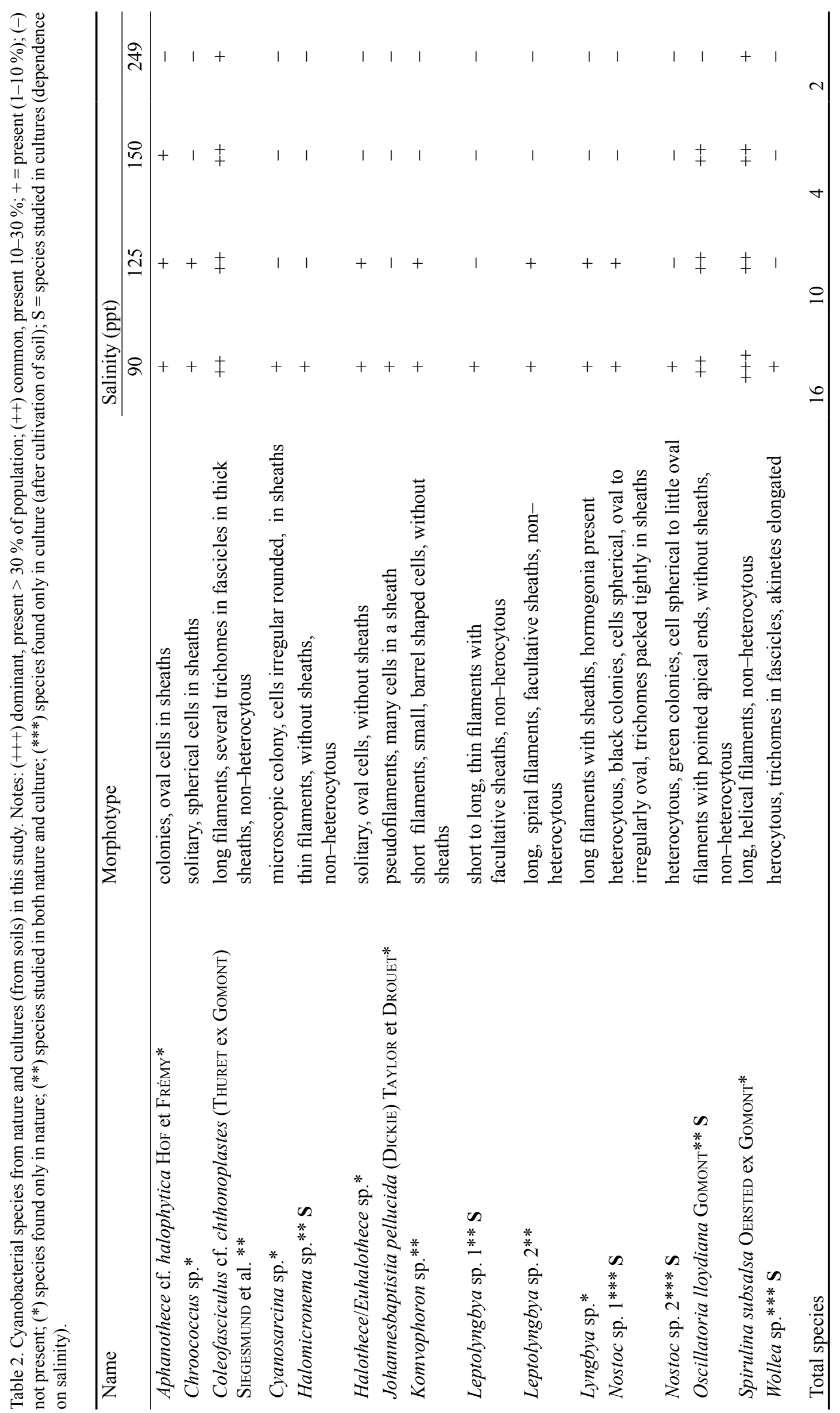




\section{a Leptolyngbya sp. 1}

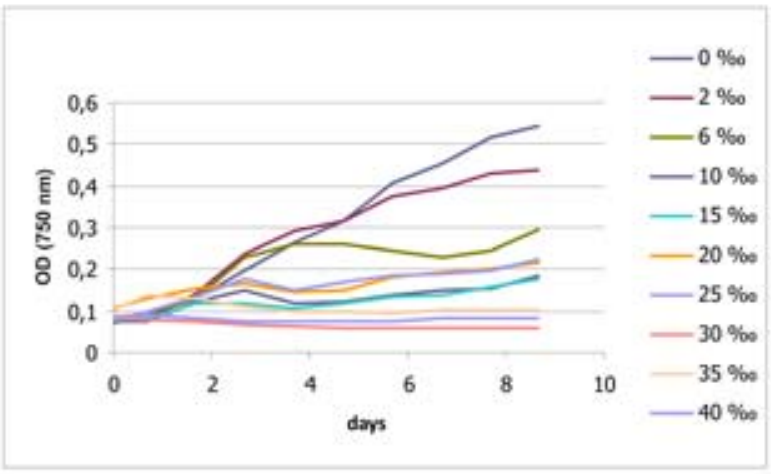

\section{c Nostoc sp. 1}

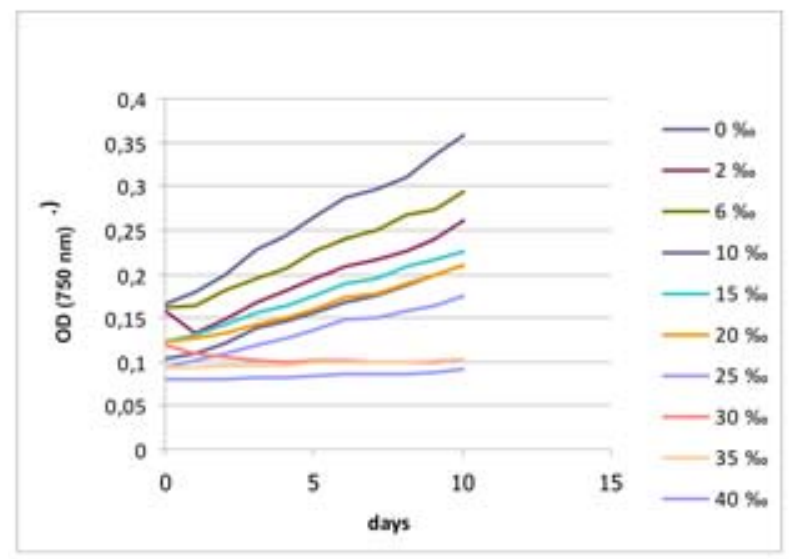

b Wollea sp.

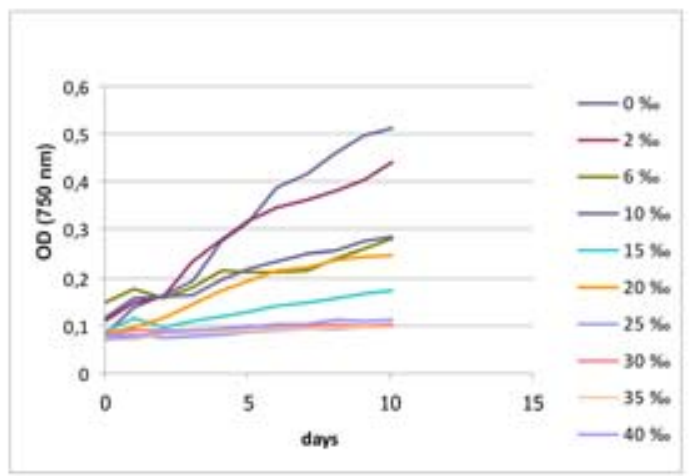

d Nostoc sp. 2

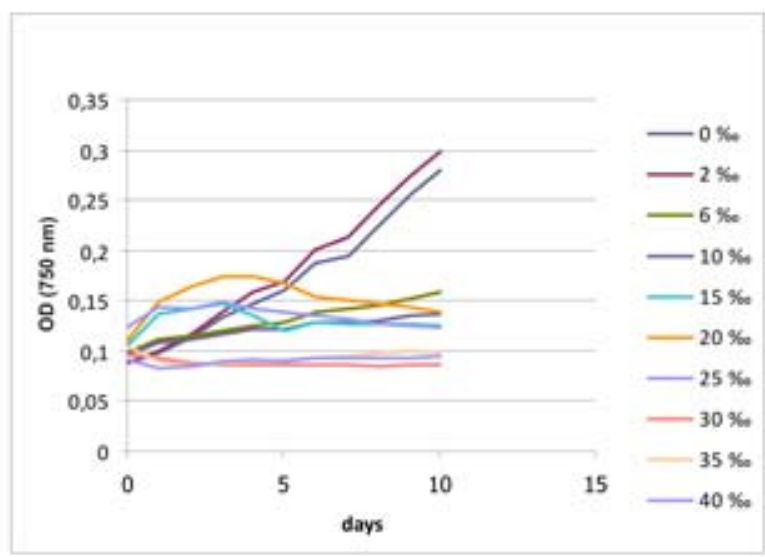

Fig. 4. The growth of four strains isolated from our localities, cultured in various concentrations of salt under temperature around $30{ }^{\circ} \mathrm{C}$ and light intensity $32 \mu \mathrm{mol} \cdot \mathrm{m}^{-2} \cdot \mathrm{s}^{-1}$. The growth was evaluated according to optical density of suspension: (a-c) halotolerant strains; (d) Nostoc sp. 2 is not adapted to saline habitats. Orig.

\section{Wollea sp. (Fig. 3e-f)}

Colonies filamentous, blue-green, rough, waved; trichomes usually packed in fascicles, or rarely \pm solitary, straight to slightly curved, with the same width along whole filaments, not branched, slightly constricted at the cross walls; individual sheaths not distinct; cells blue-green, cylindrical to barrel shape, nearly isodiametric to slightly longer than wide; apical cells acute rounded; heterocytes occurred intercalary; akinetes elongate, larger than vegetative cells and usually attach to one side of heterocytes, \pm developing in unsuitable condition. - Note: Our populations correspond to the genus Wollea, but they differ ecologically and morphologically from up to date described species. Occurrence: This species was registered only from culture, isolated from a soil sample. In the early stage of cultivation, this species does not form heterocytes and appears morphologically similar to Komvophoron sp.

\section{Dependence on salt concentration}

Dependence on salt concentration was preliminarily studied in several our isolated strains (Table 2, designated by $\mathbf{S}$ ). In all studied strains was found the maximal growth in small salt concentrations, and the decreasing growth intensity was detected with increasing salinity (examples see in Fig. 4a-c). This dependence was characteristic also for species, the growth of which is known preferentially in studied salterns, and which were not registered in other environmental localities and other habitats.

The halotolerance can be considered even as a typical marker of cyanobacterial populations adapted to salinic ecosystems. The only exception from our populations was Nostoc sp. 2, which was isolated from soils and never was found in halophilic localities in intense development. It grows in experiments only in very low salinity 
and dies in concentrations over $5 \%$ (Fig. 4d). Its diaspores were evidently transported in salterns, which are open to the influence from environmental regions.

\section{Discussion}

Cyanobacteria are ancient microorganisms, which have been presented from 2.8 billion years ago (Olson 2006). They can be found in various environments from freshwater to terrestrial habitats and also in extreme environments. In hypersalinic biotopes such as salterns, cyanobacteria form microbial mats with other microorganisms (OREN 2000). They play an important role as primary producers in these ecosystems (Golubić 1980; BorowitzKa 1981; JAVOR 1989; OrEn \& SECKBACH 2001).

Adaptation of various cyanobacterial populations to salinic and hypersalinic habitats is still the urgent problem. The growth experiments in various salt concentrations confirm that most species were halotolerant rather then halophilic. Our experimental results confirm also the previous data from literature (Golubić 1980; KoMÁreK \& LuKAVSKÝ 1988; etc.). According to our results, especially Spirulina subsalsa, Coleofasciculus chthonoplastes and Oscillatoria lloydiana should be considered as tolerant species due to their being found throughout the whole area with salinities ranging from $90-249 \mathrm{ppt}$.

Numerous cyanobacteria found in this study are also reported from other hypersalinic habitats over the world (HoF \& FrémY 1933; JAVOR 1989; Garcia-Pichel et al. 2001; Burns et al. 2004). In the Petchaburi solar saltern, cyanobacteria often occurred in green microbial mats formed on the surface layer of wet soil (approximately up to $0.5-1 \mathrm{~cm}$. thick). These mats were mostly composed of Microcoleus (= Coleofasciculus) cf. chthonoplastes, Spirulina subsalsa, Oscillatoria lloydiana and Leptolyngbya spp., rarely of Johannesbaptistia pellucida, sometimes mixed with coccoid types including Cyanosarcina sp., Aphanothece cf. halophytica, Halothece sp. and Chroococcus sp. In comparison with other hypersalinic biotopes, these localities are slightly different in species composition of cyanobacteria. E.g., in the southern part of the Great Salt Lake (Utah, USA), cyanobacteria play a minor role in photosynthesis and form their mats in shallow sites. They are composed mostly of Oscillatoria sp. and
Aphanothece sp. (OrEn 2002). Other filamentous genera, including Phormidium, Microcoleus, Spirulina, and Nodularia spp., were also found in this lake (Post 1977; Oren \& Seckbach 2001). Cyanobacteria produced microbial mats up to $1 \mathrm{~m}$ thick on the bottom of Solar Lake, Sinai (Egypt). These were rich with biogenic carbonate and dominated by the unicellular Aphanocapsa littoralis and Aphanothece halophytica, and the filamentous Microcoleus sp. and Oscillatoria sp. (JørGensen \& COHEN 1977). The planktonic gasvacuolated cyanobacterium "Dactylococcopsis" salina (= Myxobactron salinum) was described from this locality (WALSBY et al. 1983). Moreover, the diversity of stromatolites forming in hypersaline marine waters at Shark Bay, Western Australia was characterized by cyanobacteria from the genera Synechococcus, Xenococcus, Microcoleus, Leptolyngbya, Plectonema, Symploca, Cyanothece, Pleurocapsa and Nostoc (Burns et al. 2004). According to this study, the number of cyanobacterial species declined with higher salinities. This result correlates with the study of Nagasathya \& ThaJUdDin (2008) in saltpans of the southeastern coast of India and is in agreement also with our results (СHATCHAWAN et al., in prep.).

In many hypersaline environments, such as hypersaline lakes, cyanobacteria occur predominately as isolated unicellular types, in colonies and filamentous agglomerations. Caumette et al. (1994) report the species compositions of microbial mats from a Mediterranean saltern in France during the warm season. The top brown layer was composed of the unicellular cyanobacterium Aphanothece spp. while the intermediate green layer was formed by Phormidium sp. In addition, the cyanobacterial community in Grande coastal lagoon, Lima, Peru was mainly composed of coccoid colonies and filamentous cyanobacteria, diatoms and some green algae (Montoya 2009). In the Petchaburi solar saltern, cyanobacteria usually occurred in mats and were mostly dominated by filamentous cyanobacteria. Some species of diatoms, including Amphora sp. and Nitzschia spp., mixed with communities of cyanobacteria. It follows from all of these findings that hypersaline habitats are only similar in cyanobacterial diversity (cf. KIRKWOOD et al. 2007). Cyanobacteria were found often mixed with diatoms and some green algae.

The probably cosmopolitan cyanobacterium "Microcoleus chthonoplastes"(= Coleofasciculus 
chthonoplastes) (GARCIA-PICHEL et al. 1996; SiEgesmund et al. 2008) was reported from various hypersaline environments worldwide. In the Petchaburi solar saltern, C. chthonoplates was usually found with other cyanoprokaryotes, including Leptolyngbya spp., Spirulina subsalsa and Oscillatoria lloydiana. These findings are similar with the report of cyanobacterial taxa in the Grande coastal lagoon, where C. chthonoplastes ("Microcoleus") was mainly associated with Aphanothece stagnina(?), Spirulina subsalsa, Calothrix crustacea(?), Lyngbya aestuarii and Johannesbaptistia pellucida (Montoya 2009). Solar Lake, Sinai peninsula, was colonized by Aphanothece halophytica, Microcoleus chthonoplastes, Spirulina subsalsa and Oscillatoria salina (CAMPBELl \& Golubić 1985).

Our study provides information about the appearance and diversity of cyanobacteria in saltern habitats in Thailand. Our studies continue, the hypersaline habitats have distinct cyanobacterial microflora, but the different localities in various geographical regions evidently differ in their diversity as well as in local ecological conditions. The diversity of microorganisms in hypersaline environments in Thailand salterns is relatively low. We have used only morphological characteristics of various species as a basis for further research. Cyanobacterial diversity may be more diverse than we demonstrated. Therefore, further study by other techniques, including cultivation and molecular methods (DGGE or sequencing), should be applied. Detailed taxonomic evaluation and study of the ecological characteristics of various isolated species from our localities will follow in the next part of our research.

\section{Acknowledgments}

We gratefully thank the Thailand Research Fund through the Royal Golden Jubilee Ph.D. Program (Grant No.Ph.D 0225/2549), the TRF/BIOTEC Special Program for Biodiversity Research and Training Grant BRT T_149014 for providing financial support to this research and the grants AV0Z60050516 and GACR 206/08/0318 (J. Komárek). We also thank Dana Švehlová for laboratory assistance and Thanaphon Yooyen for field assistance. English correction was made by Keith Edwards.

\section{References}

Abed, R.M.M., Garcia-Pichel, F. \& HernándeZMARINÉ, M. (2002): Polyphasic characterization of benthic, moderately halophilic, moderately thermophilic cyanobacteria with very thin trichomes and the proposal of Halomicronema excenticum gen. nov., sp. nov. - Arch. Microbial. 177: 361-370.

BorowitzKa, L.J. (1981): The microflora: Adaptation to life in extremely saline lakes. - Hydrobiologia. 81: 33-46.

Burn, B.P., Goh, F., Allen, M. \& Neilan, B.A. (2004): Microbial diversity of extent stromatolites in the hypersaline marine environment of Shark Bay, Australia. - Environ. Microbiol. 6: 109 -1101 .

Campbell, S.E. \& Golubić, S. (1985): Benthic cyanophytes (cyanobacteria) of Solar Lake (Sinai). - Arch. Hydrobiol. 71: 311-329.

Caumette, P., Matheron, R., Raymond, N. \& Relexans, J.C. (1994): Microbial mat in the hypersaline pond of Mediterranean salterns (Salins-deGiraud, France). - FEMS Microbiol. Ecol. 13: 273-286.

Dassarma, S. \& Arora, P. (2001): Halophiles. Encyclopedia of life science. 8: 458-466.

Dennis, P.P. \& Shimmin, L.C. (1997): Evolutionary divergence and salinity-mediated selection in halophilic archaea. - Microbiol. Mol. Biol. Rev. 61: 90-104.

Garcia-Pichel, F., Prufert-Bebout, F. \& Muyzer, G. (1996): Phenotypic and phylogenetic analyses show Microcoleus chthonoplastes to be a cosmopolitan cyanobacterium. - Appl. Environ. Microbiol. 62: 3284-3291.

Garcia-Pichel, F., Nübel, U. \& Muyzer G. (1998): The phylogeny of unicellular, extremely halotolerant cyanobacteria. - Arch. Microbiol. 169:469-482.

Garcia-Pichel, F., Lopez-Cortes, A. \& Nübel, U. (2001): Phylogenetic and morphological diversity of cyanobactera in soil desert crusts from the Colorado Plateau. - Appl. Environ. Microbiol. 67: 1902-1910.

Gilmour, D. (1990): Halotolerant and Halophilic Microorganisms. - In Edwards, C. (ed.): Microbiology of extreme environments. pp. 147-177, Open University Press, Milton Keynes, UK.

Golubić, S. (1980): Halophily and halotolerance in cyanophytes. - Original of Life. 10: 169-183.

Hof, T. \& Frémy, P. (1933): On myxophyceae living in strong brines. - Rec. Trav. Bot. Gnarl. 30: 140-162.

JAVOR, B.A. (1989): Hypersaline environments. Microbiology and Biogeochemistry. Springer - Verlag, Berlin, Germany.

Jørgensen, B.B \& Cohen, Y. (1977): Solar Lake (Sinai). 5 . The sulfur cycle of the benthic cyanobacterial mats. - Limnol. Oceanogr. 22: 657-666.

Kirkwood, A.E., Buchheim, J.A, Buchheim, M.A. \& 
Henley, W.J. (2007): Cyanobacterial diversity and halotolerance in a variable hypersaline environment. - Microb. Ecol. 42: 537-547.

KomÁreK, J. \& Anagnostidis, K. (1998): Cyanoprokaryota 1. Teil: Chroococcales. - In: Ettl, H, Gärtner, G., Heynig, H. \& Mollenhauer, D. (eds): Süsswasserflora von Mitteleuropa 19/1. - 548 pp., Gustav Fischer Jena-Stuttgart-Lübeck-Ulm.

Komárek, J. \& Anagnostidis, K. (2005): Cyanoprokaryota 2. Teil: Oscillatoriales. - In: BÜDEL, B., Gärtner, G., Krienitz, L. \& Schagerl, M. (eds): Süsswasserflora von Mitteleuropa 19/2.760 pp., Elsevier GmbH, München.

KomÁrek, J. \& LukAvskÝ, J. (1988): Arthronema, a new cyanophyte genus from Afro-Asian deserts. Algological Studies 50-53: 249-267.

Margheri, M.C., Ventura, S., KaštovskÝ J. \& KomÁREK, J. (2008): The taxonomic validation of the cyanobacterial genus Halothece. Phycologia 47: 477-486.

Montoya, H. (2009): Algal and cyanobacterial saline biofilms of the Grande coastal lagoon, Lima, Peru. - In: Oren, A., Naftz, D., Palacios, P. \& WurtsDaugh, W.A. (eds): Saline Lakes around the World: Unique Systems with Unique Values, Natural Research and Environmental Issues Volume 15. - pp. 127-134

Nagasathya, A.\&Thajuddin, N.(2008): Cyanobacterial diversity in the hypersaline environment of the saltpans of southeastern coast of India. - Asian J. Plants Sci. 7: 473-478.

Olson, J.M. (2006): Photosynthesis in the archean era. - Photosynth. Res. 88: 109-117.
Oren, A. (2000): Salt and brines. - In: Whitton, B.A. \& Potтs, M. (eds): The ecology of cyanobacteria: Their diversity in time and space. - pp. 281306, Kluwer Academic Publishers. Dordrecht.

Oren, A. (2002): Halophilic microorganisms and their environments. - 575 pp., Kluwer Academic Publishers. Dordrecht.

Oren, A. \& Seckbach, J. (2001): Oxygenic phothosynthetic microorganisms in extreme environments. - Nova Hedwigia 123: 13-31.

Post, F.J (1977): The microbial ecology of the Great Salt Lake. - Microb. Ecol. 3: 143-165.

Satyanarayana, T., Raghukumur, C. \& Shivaji, S. (2005): Extremophilic microbes; diversity and perspectives. - Curr. Sci. 89:78-90.

Siegesmund, M., Johansen, J., Karsten, U. \& FriedL, T. (2008): Coleofasciculus gen. nov. (Cyanobacteria): Morphological and molecular criteria for revision of the genus Microcoleus Gomont. - J. Phycol. 44: 1572-1585.

Walsby, A.E., Riuin, V.J. \& Cohen, Y. (1983): The biology of a new gas-vacuolate cyanobacterium Dactylococcopsis salina sp. nov., in Solar Lake. - Proc. R. Soc. Lond. B. 217:417-447.

(C) Czech Phycological Society (2011)

Recieved Sept 2010

Accepted Dec 2010 